\title{
Critical analyses of church politics and crises within the indigenous Christianity in Nigeria
}

\author{
Alokan Olusegun Ayodeji Peter, Alabi David Oladunjoye and \\ Babalola Sunday Funmilola \\ Department Of Religious Studies, Joseph Ayo Babalola University \\ Ikeji-Arakeji, Osun - State
}

\begin{abstract}
Politics, disloyalty, oppression, tussle for leadership power and divisions seemed to have characterized the indigenous Pentecostal churches in Nigeria particularly in the last two decades of the twentieth century. Historically, the underlining factors for the occurrences in the Nigerian indigenous Christianity in recent times could be traced to doctrinal practices, leadership problems, different interpretations and manipulations of prophetic gifts and sundries. Today, some church pioneers have been alleged of playing double standard through their actions in the running of church affairs. Some also have accused of false biblical teachings resulting at times to fake prophecies and revelations. These attitudes have negative implications on church growth and on church membership
\end{abstract}

\section{INTRODUCTION}

\section{BACKGROUND}

The paper attempts to trace the history of indigenous churches in Nigeria. It examines further the problems arising from church practices particularly at the formative periods. For better understanding, the paper could be sub-divided into the following;

1.The advent of indigenous Pentecostal Groups

2.General Reasons for politics and divisions amongst indigenous Pentecostal Group

3.Perspectives for unity and Ecumenical
understanding

\section{Findings/Recommendations}

The Advent of Indigenous Pentecostal Groups: Christianity came to the shores of Africa through Portuguese traders in the fifteenth century. In 1480, the Gospel was first preached in the Benin and Warri areas of the present Edo and Delta States of Nigeria (Omoyajowo, 2001: 10-11).However, not until about the middle of the nineteenth century, did the new religion, Christianity got deeply rooted in the interior parts of Nigeria.

By 1846, the gospel in its Anglican version reached the major cities in Yoruba land (Abeokuta, Lagos and Badagry) through the efforts of the missionary bodies in Europe and North America. (Olayiwola, 2009: 1-2) One of the missionary bodies destined to play an extensive role in Nigeria was the Church Missionary

Society (CMS) because of its wider influence. (Thorogood, 2010: 1-4) The Society had earlier played a significant role in impacting Christian lives on the ex -slaves deposited in Freetown, Sierra Leone by the British government in 1804. Some of these educated slaves later became prominent in the evangelical outreaches in Africa, and particularly in Nigeria. One of the most outstanding figures was Samuel Ajayi Crowther, a freed slave who later became the first African Bishop of the Anglican Church in the Delta province of Nigeria in West Africa. (Oshun, 1981: 1-5)

There is no doubt that the Christian Missionary Society achieved a lot in the evangelization and exploration of Nigeria in the first quarter of the nineteenth century in spite of the difficulties and challenges encountered. The Niger expedition of 1841 organized by the C.M.S. under the leadership of J.K. Schon and Samuel Crowther was not completely successful. Yet, the C.M.S. through this expedition had gone a long way to establish visions and desires for its organization, and was a pace-setter for other Christian churches that later arrived in Nigeria. 
The cordial relationship between the white missionaries and the Africans in Nigeria became strained in 1885. In the first instance, the Nigerians who attended the mainline churches, particularly the Anglican Church, were bored with the style of worship which seemed monotonous to them.(Oshun,1981:2). Oshun therefore referred to Mitchell by saying, "What motivated the African leaders and their followers was the desire to reform existing Mission Protestant Christianity and make it more relevant to the needs of the daily African life"

Ogbu Kalu in his research work on African Pentecostalism linked the history of the African Independent Churches to the beginning of indigenous Pentecostalism in Nigeria. He stated "In the nineteenth century, prophetic figures emerged in one place after another.... The movement could be regarded as the first response by Africans. It challenged white monopoly of the cultic and decisionmaking powers within the church, and the monopoly of the interpretation of the canon and the cultural symbols of worship" (Kalu, 2008: 23-24).

However, Ayegboyin and Ishola (1997:21) disagreed with this view believing that the African Independent Church was as a result of the reactions of the indigenous in Nigeria against leaders of the mainline churches for discrimination. According to these writers, the African Independent Churches were a result of the reactions towards the alteration of the church indigenization policy of Rev Henry Venn (the Anglican

Church Secretary) by his successor Rev J.S. Hill after the death of Samuel Ajayi Crowther. Henry Venn source had earlier suggested that the Nigerians should be properly trained in such a way that they would coordinate church activities without the involvement of foreign missionaries. But, Hill did not follow this policy of indigenization after the death of Samuel Ajayi Crowther but rather chose to appoint a white bishop as his successor.

Consequently, many Africans protested, particularly when the Nigerian pastor of the Baptist Church Lagos (M.L.Stone), was dismissed from office. (Website, 1964: 45). This finally led to a split in the Baptist Church with Mojola Agbebi as the leader in 1888. (Ayegboyin \& Ishola, 1997:22). Other Churches followed this pattern of split: The Native Baptist Church (1888), The United Native African Church (1891), The African Church (1901) with J.K. Coker as leader and The United African Methodist Church Eleja (1917). (Grimley \& Robinson:301).
This development stimulated the emergence of charismatic leaders in Nigerian Christianity. These charismatic preachers used to have large followers because of the gifted power for signs and miracles through their evangelistic revivals and programs conducted in different localities of Nigeria. Prominent among them was Garrick Braide from the Niger Delta area of Nigeria. He started his ministry in about 1916 and in the following year had penetrated into the interior parts of Delta State and Igbo land. (Olayiwola, 2009:5).

The Beginning of Indigenous Pentecostalism in Nigeria: Pentecostalism has been associated with the gifts of the Spirit particularly in the aspects of speaking in tongues and interpretations (Macchia, 2002: 897).Thus, the events in Acts of Apostles chapter two served as a bedrock for the Pentecostal movement; it was on Pentecost day the church was revealed by the Holy Spirit (Nyamiti, 2007: 26). It also deals with holiness, constant prayers and preaching the gospel through the working of miracles. It is against this background that the history of Pentecostalism in Nigeria was formed.

The question that may come up is: how did Pentecostalism reach Nigeria? Historically, it started from America in Los Angeles under the leadership of Charles Parham in 1901. (Kalu, 11). He was the first person to link baptism in the Spirit with glossolialia. His mission was purely based on "empowerment for mission and ministry" (Anderson, 2004: 8-9 \& 101106). This later turned to a revival that pulled crowd in Azusa street in Los Angeles. Here, the revival was masterminded by a black pastor, William J. Seymour. (Hacken, 2005: 900).

Within two years of the Azusa street outbreak, the Pentecostal movement had branches throughout the United States and in many Northern European countries in India, China and South Africa. It was during this period that the revival got to Nigeria. (Ibid, 900) Although the Pentecostal ministry from Los Angeles was short lived in Nigeria, it served as a background for the indigenous Pentecostal movements that sprang up in the early twentieth century, particularly the Prayer Group Movements in 1918 (Marshall, 2009: 45-52).

The Prayer Group Movements: As earlier mentioned in this study, the African Independent Churches emerged as a result of the reactions against the foreign Christian style of worship. However, Peel, a historian confirmed in his book that the efforts of these African Independent Church leaders did not completely meet the spiritual needs of 
the populace particularly in the aspect of worship and liturgy-(prayers, songs, dancing and addressing). (Peel, 1968: 57). They followed the style of prayer, worship and songs of the Roman Catholic and other mainline churches. The only change in fact was from the use of English as worship language to vernacular language. The desire of the indigenous worshippers was to dance and sing in local dialects and receive prophetic messages and revelations about their future, worries and deliverances from the power of darkness or demonic spirits. (Peel, 1998:58).

Thus, in 1917-1918, there were reports of spiritual revival ministries of an Evangelist called Egunjobi whose profession was hunting before he received the call of God as well as Evangelist Babamuboni who was formerly an Anglican catechist. These two personalities organized in different regions of Yorubaland prayer groups for evangelical outreach and soul winning. (Peel 196:69). In 1918, a similar group sprang up in ljebu-Ode in Nigeria, by some group of people under the leadership of Joseph Shadare. The group was later known as the Precious Stone Movement.

Historically, this movement started through a vision from Daddy Ali (as he was named). He claimed to have received a revelation about the calamity that would befall the Anglican Church where he served as a sexton. The period under discussion was also characterized with epidemic disease that claimed the lives of thousand of children and youths in Yoruba land, Nigeria. Ali narrated his vision to Rev. Gansallo, the presiding minister of his church at Saint Saviour's Anglican Church, ljebu-Ode. The white priest did not regard the revelation as something so important but ignored it as mere illusion. (Alokan, 2010:15 \&16).

Shortly afterwards, Ali had another revelation, similar to the first one. (Olowe, 2007: 68). This time, he went to relate it to four elders within the Anglican Church. Consequently, Daddy Ali bypassed the ruling authority of the Anglican Church and organized a prayer session with these four elders namely; J.B.Shadare, E.O. Onabanjo. D.C.Oduga and E.O.W. Olukoya. They met regularly for prayers and under the leadership of Joseph Shadare who was also known as Esinsinade.

It must be noted that the emergence of the Precious Stone Movement caught the white Anglican priests off-guard. They reacted negatively because the idea of organizing a separate prayer group within the church (Anglican) was against its standard norms and regulations. Finally, the leaders of this Movement were sent away from the Anglican Church because they kept on meeting in spite of several warnings from the Anglican priest. (Olowe: 2007:69). Thus, the Precious Stone Movement became a separate group.

The members of the Movement met regularly for prayers and spiritual instructions. They met in different places; on mountains and other secluded places for prayers. They held Bible studies in different homes of members; and in the course of time, they spread to many parts of Yoruba land, such as Lagos-State, Abeokuta, ljebu, Ilesha, Akoko,Benin and Kano (Olowe:68 \& 70).

The Faith Tabernacle Congregation - Prelude to Politics and Divisions: The Precious Stone Movement under the leadership of Joseph Shadare blossomed into a group,popularly called Faith Tabernacle of Nigeria, in 1920, with its headquarters in Philadelphia, America. The American Faith Tabernacle was a Pentecostal tract ministry headed by Pastor Clark purposely to reach many areas in the world for the Christian faith. (Alokan, 1971: 13). Members of the Precious Stone Movement had contact with this ministry through one of the prayer group members named David Odubanjo. He had relationship with the America Faith Tabernacle through its quarterly magazine, The Sword of the Spirit when he was working with the railway station in Warri, Nigeria. (Welsh,1976: 418). This contact greatly influenced the early preaching and evangelism of the Precious Stone Movement which was later called "Fate Tabernako" (Faith Tabernacle) in the local language by those that heard their preaching and received the magazine. (Welsh, 1976:418).

The Faith Tabernacle started well with impressive news of miracles and expansion in Nigeria.(Ayegboyin \& Ishola, 1997: 71). But, after a period of about four years association, members of the Faith Tabernacle in Nigeria began to lose confidence in the American leadership. (Ayegboyin \& Ishola, 1997:71). First, the Nigerian members were skeptical about the Pentecostal perspectives of the American Faith Tabernacle leaders, which they thought were completely different from their teachings. Also, the Nigerian members were disappointed that the American fellowship never bothered to send missionaries to Africa but only related with them by means of correspondence. (Oshun, 1983: 105-114). Odubanjo therefore wrote to the American Faith congregation to clarify some 
issues on prophetic healing, evangelism and church organization.

The reply was unfavorable and the Americans described Pentecostal "tongue-speaking" as delusion and satanic.( Ayegboyin \& Ishola, 1997: 71) The reply stated thus: "Dear Brother in Christ,....We are so surprised that you have permitted Satan to put into your heart to lay aside the office and ministry in Faith Tabernacle at Philadelphia that has proven such an instrument of blessing to you in the past... (Alokan, 2010:34). This reply created untold confusion in the minds of the Nigerian members and eventually led to another division and separation in 1929. (Alokan, 2010:34).

The Emergence of Christ Apostolic Church: There are conflicting narrations about the history and development of the Christ Apostolic Church (CAC).Some historians like J.D.Y.Peel, David Olayiwola and Akinyele Omoyajowo trace the emergence of the Christ Apostolic Church to the 1918 episodes of the Precious Stone Movement which surfaced in ljebu-Ode, Nigeria. 'The reason being that many leaders of the prayer group (Precious Stone Movement) and Faith Tabernacle congregation were also the leading members of the Christ Apostolic Church in later years. There were also other writers like Elijah Olusheye, Abi Olowe and Ojo Matthews who linked the upsurge of the Church with the subsequent events that took place from 1930 upwards. This event has to do with the emergence of a prophetic minister named Joseph Ayo Babalola. His ministry spread through the 1930s and 1950s. (Omoju, 2000:7).Joseph Ayo Babalola received the call of God on three occasions namely, $9^{\text {th }}, 10^{\text {th }}$, and $11^{\text {th }}$ October 1928 at 12:00noon with prophetic and divine instructions on divine healing. In November 1928, he started an evangelical campaign in parts of Yoruba land; but was rejected in his hometown, OdoOwa in the early April 1929 because of his prophetic revelation that a wild animal would come to the town and destroy the people within 45 days from the time of his preaching if they did not repent and turn to God. (Olowe, 2007:102-103). However, the wild animal was later referred as the epidemic disease that broke out in the town six months after the prophecy

Babalola ministry was not only limited to this town but was extended to ministry to non- Yoruba land of Nigeria in June 1929. Also, he joined The Faith Tabernacle Movement when it was at the verge of collapsing as a result of internal crisis. By August 1929, Babalola and his followers met with the Faith
Tabernacle in Nigeria for discussion with Daniel Ajibola as a linkman for the two groups. He resided in Ibadan, Nigeria. (Welsh, 1976:419). In that meeting, Babalola gave a full account of his calling into the ministry and the main message of evangelism and preaching. The leaders of the Faith Tabernacle, who had gathered at Odubanjo's house in Lagos joyfully accepted his message and God's call upon him joyfully. This marked the coming together of the two religious groups and in 1930, revivals began earnestly (Welsh, 1976: 419).

By February 1931, David Odubanjo, made another attempt to establish a relationship with a Pentecostal foreign mission named The British Apostolic Church, since his group had separated from the Nigerian or American Faith Tabernacle in 1929. The white missionaries arrived in Nigeria (August 1931) to finalize agreement on how the ministry would take off. History confirmed that the ex-leaders of Faith Tabernacle including Joseph Babalola received these white missionaries with a welcome service. (Alokan O.A.2006: 91-unpublished) The outcome was the establishment of the Nigerian Apostolic Church with its headquarters in Britain. The relationship lasted for about eight years before divisions set in.

Schism and Secession in Christ Apostolic Church: As earlier stated in this study, the relationship between the Nigerians and the British Apostolic Church became strained as from 1939. The problematic issue was the question of divine healing. Some leading members of the Nigerian Apostolic Church raised eyebrows against the white missionaries who took medicine, quinine in particular as preventive cure against malaria which was rampant in Nigeria then. The Apostolic Church in Nigeria believed that taking medicine was a breach of agreement on the doctrine of divine healing which had been the basis of their teachings right from inception. Therefore another separation occurred. (Alokan 2010:320).

The separated group consists of the majority and they took the name Christ Apostolic Church with Pastor(Oba)Isaac B Akinyele as the president, Joseph Ayo Babalola as the General Evangelist and David Odubanjo as the General Superintendent, in 1940.The Church became officially registered in 1943 (Alokan, 1991:92). The church believes strongly in divine healing, holiness and reliance on God for provisions rather than borrowing from the bank or financial houses. 
In 1990, a controversy occurred in the Christ Apostolic Church between some young and zealous pastors and the church authority over doctrinal practices (particularly on divine inspiration and faith in God without borrowing money or incurring debt from bank) and the abuse of prophetic gifts. (Welsh, 2005: 200). There were other complaints which have to do with the sudden emergence of charismatic and gifted ministers (special reference to Pastor Timothy $O$ Obadare) who were alleged to be running parallel administrations and ministries within the church. In the early 70s, Timothy Obadare, a gifted and charismatic minister claimed to receive a divine instruction to organize a praying group within CAC and named it "Soul Winning Evangelical Group" (WOSEGRP). Soon, he extended the membership of the Group not only to members in CAC districts but also to non-CAC members across the country. He later transformed the group to a ministry called Soul Winning Evangelical Ministry (WOSEM), popularly known as Koseunti. (Alokan, 2010:450).

Other ministries began to spring up speedily within the CAC as from the early 80s. For instance, "The Agbara Olorun Kii Bati Ministry" sprang up and became very popular under the leadership of a woman called Bola Odeleke. She later opted out finally from CAC in the late 1990 and was consecrated as a Bishop of newly created "Agbara Olorun Kii Bati Church" in 1998. Similarly, a popular singer in the church named Bola Are founded a ministry called, "The Spiritual Covenant Gospel Singers Internationals". The Ministry became well known in Africa and overseas. Also, S.K. Abiara founded "The CAC Agbala Itura Worldwide". He was also the president of a ministry named "Christ International Evangelistic Ministry". This Ministry was well known in America and in the West African subregion. (Alokan,1991:239\&240). Most of these Ministries have their own Bible Schools, Nursery and Secondary Schools, Printing Presses, and separate Constitution among other things. The CAC initially attempted to manage and control these crises, but however, the controversies got out of hand. The leaders of the Church were hasty in deciding to discipline the vocal pastors; while they too were not patient enough before taking the church authority to Court of Law to settle the scores involved. This was contradictory to the doctrine and teachings of the church. The youths at the local level did not help matters as they campaigned against the teachings of the church on divine healing and against church restrictions of students in higher institutions of learning from studying courses related to medicine, law and banking and finance.

Also, some ministers who were caught in the acts of immorality and abuse of power in the church refused to be subjected to discipline from the church authority. For example, in 1977, Prophet Oluwani Durojaiye of CAC Oke-Aanu Akintola Road,Ibadan was alleged of immorality but refused sanctions. He took further steps in annoyance to preach against the church authority and disobeyed the church leaders. Consequently, Durojaiye pulled out of the CAC and formed a new church called The Blood of Jesus Apostolic Church(Alokan,2010:450\&460)

Thus, the crisis which started on the level of administration within the church ended with the emergence of three groups popularly called in the local context as General Executive Council, Supreme Executive Council and The Christ Initiative Forum. (Alokan, 2000:201).The Forum group initially classified itself as peace makers but ended up taking sides with the General Executive Council. This made the story complicated and interesting as the Forum group split into two, namely, "The Working Policy Committee" and "The Interim" These two groups till now have not been in good terms. (Alokan, 2000:201 \& Olusheye 2010:66-69)

The Forum group became very influential in decision making during this time. The group consisted of wealthy people, learned fellows and elites. Some members of this group used their positions to influence court cases, bought positions and change church policies in their favour. Some members of forum group became so powerful to the extent of directing the affairs of the church to the point of dictations, some bought houses, cars etc for church leaders so as to find ways to the corridors of power. One radical step taken by the forum group was the enforcement of the church policy on retirement. This actions led to the retirement of the three principal officers of the church then namely Joseph Orogun (President of the church), Abraham Ade Olutimehin (General Superintendent) and David Babajide (General Evangelist). (Alokan, 2000: 201). From July 1963, the age-limit of retirement in the Church had been fixed at 70 years.

However, all along, the regulation had not been enforced. But now that all the principal officers were octogenarians, the group advised them to resign their appointments giving six months notices with effect from that time. This decision led to the struggle for leadership positions in the church. Many church 
leaders died in the struggle and also some church buildings were closed down temporarily because of the crisis. At last, the church was administratively split into two in 1992, but both groups still bear the name Christ Apostolic Church, with different leaders. The majority group is headed by Elijah Olusheye and the minority is headed by Adenekan and Udofia and assisted by the renowned Evangelist Timothy Obadare

The Emergence of Cherubim and Seraphim Church: One of the most prominent events in the first half of the twentieth century was the emergence of the Cherubim and Seraphim Church. It started as a prayer movement just about the time when the Faith Tabernacle was taking shape. This movement was established in 1925 by Moses Orimolade Tunolase. $\mathrm{He}$ was a native of Ikare in Akokoland, Ondo-State, Nigeria. He was born in the 1870's with a crippled leg. (Ayegboyin \& Ishola, 2007:81) Just before he began his ministerial assignment, he claimed to have received a vision in which he was asked to drink and bath with some water from a nearby flowing stream. (Ayegboyin \& Ishola, 2007:81).

According to Ayegboyin and Ishola,"Orimolade obeyed this divine instruction but recovered only partially from his infirmity for he still limped for the rest of his life" (Ayegboyin \& Ishola, 2007:81). The personal miracle experienced by Orimolade encouraged him to start the work of God as a travelling preacher. Between 1920 and 1924, he journeyed to many parts of Yorubaland, Bendel (now Edo) state and Northern Nigeria, and preached the Christian faith. His ministry became known to many people in Nigeria only with the raising to life of a 17 year old girl name Abiodun Christianah Akinsowon in 1925 in Lagos (Alokan, 2010: 502).

History confirmed that Akinsowon went to witness the annual celebration of the Catholic Corpus Christi procession in Lagos. Here, she became ill and assumed to have fallen into a trance. She was later rushed home for care but the trance continued for many days. (Alokan, 2010:502). However, Orimolade who was in Lagos for evangelical work at the time of the incident was invited by Akinsowon's guardian to pray for the lifeless girl. This he (Orimolade) did, and the young girl recovered from her trance. That was how Akinsowon became a church member and later next in rank (with a title "Captain") to Orimolade in the ministry which was in 1926 called Cherubim and Seraphim Church.
Schism and Secession in Cherubim and Seraphim Church: The Cherubim and Seraphim Church (C\&S) under the leadership of Orimolade spread quickly to all parts of Yorubaland in the first four years of her existence. Soon, persecution arose from the colonial government who thought his (Orimolade) teaching and preaching contradicted the guidelines for church activities in Nigeria. While this was going on, silent internal squabbles and disagreements existed among some of the leaders of the church.There was also inordinate desires to form other groups were rife; there was also the crisis of personality clash based on individuals' track records. (Alokan, 2010: 453\&454).

In 1928, there was a conflict between Orimolade and his assistant, Akinsowon. The dispute began earnestly when Captain Akinsowon challenged Orimolade over the impropriety of retaining a girl named Olayinka to stay with him in the same house. Abiodun suspected her boss (Orimolade) of committing adultery for abducting the young lady. (Alokan, 2010:503). Orimolade was annoyed by the accusation and he cursed Akinsowon in public gathering (Omoyajowo, 1982: 64).The situation became more tensed in early 1929 when some youths in the church took side with Abiodun, and thereby encouraged her to break away from Orimolade.

In the end, the unpleasant situation that followed led the two to part ways. Orimolade with the intervention of the police wrote to Abiodun: I am therefore asking you through this letter to inform you to form your own society taking with you all the members as are willing

to follow and cooperate with you. (Omoyajowo, 1982:65).

This event culminated in the adoption of the name: The Cherubim and Seraphim Church by the Akinsowon faction. The Orimolade group picked the designation: The Eternal Sacred Order of Cherubim and Seraphim Society. (Onovughakpo, 1971: 6) This marked the first schism and secession in the church.

As the movement was recovering from the shock of this schism, another disagreement arose between Orimolade and his Sacred Order prayer band. He had information that the educated elites in the praying band were trying to register a constitution without his knowledge and thereby remove him as the spiritual leader of the movement. Though, the authencity of this information may be questioned but the end result was dispute. 
By 1930, the praying band broke away and named itself the Prayer Band of the Cherubim and Seraphim under the leadership of Ezekiel Davies. (Ojo, 2001:14). This was the second secession. In 1931, representatives of the Cherubim and Seraphim branches in Lagos met with other branches in the suburb to affirm their neutrality in the headquarter crises in Lagos and to seek ways of reconciling the factions. When their appeals did not yield any positive results, they showed their displeasure by inaugurating a separate organization called The Western Conference of the Cherubim \&Seraphim (Nigeria).The group finally opted out under the leadership of Madam Christianah Olatunrinle who was later appointed the first General Superintendent. (Ayegboyin \& Ishola; 86) That marked the third secession.

In 1932, the remaining section of the Sacred Order praying band broke away and formed a new body named The Holy Flock of Christ under the leadership of Mayor A.B.Lawrence, one of the early leaders of the praying band. Lawrence pulled out of Sacred Order because he claimed to have had a vision to establish his own organization. Indeed, many people followed him. That was the fourth secession. This was a great shock to Orimolade because it was glaring the central administration of the C\&S had started to fall apart. Until his death in 1933,Orimolade ran the church from his sitting room. He hardly come out for Sunday services but dedicated some youths to run the church administration.

The fifth secession came up in October 1933.There was a struggle for headship supremacy and for other key offices in the church. However, Orimolade had indirectly appointed Abraham Onanuga, a gifted prophet but a new member of the church as the head. This action annoyed Peter Omojola, the senior brother of Orimolade who had been with him from the inception of his ministry. A faction which felt that Onanuga was not qualified to succeed Orimolade encouraged Omojola to start his own Church. He seceded and launched his Eternal Sacred Order of the C\&S (Mount Zion). (Ayegboyin \& Ishola:86).

As at 1940, the C\&S had been divided into five major streams plus a number of smaller churches; namely :Eternal Sacred Order of Cherubim \& Seraphim, Society, Praying Band of C\&S, Sacred Order, and Holy Order of C\&S Movement. (Oshitelu,2002:42). By 1968, these had increased to14 in Lagos alone. There also existed hundreds of prophets establishing Cherubim \& Seraphim Churches unaffiliated to any group. In the 70 s, many splits were coming up daily.
The Holy Apostles Community of Ayetoro sprang up in Ayetoro in the coastal area of Southwestern Nigeria where members renounced individual material possession and practiced a welfare state and communal living. Onovughakpo described the constant crises in C\&S thus:

To found one's own branch and
headquarters is as simple as
winking the eye. The procedure
is first to procure for yourself
the power of vision and
prophecy...The next step is to
approach an Apostle or Bishop
to receive the order of
Apostleship.....Then your
parlour becomes the Cathedral
Church and your room the
headquarters... (Onovughakpo,
1971:6)

However, the Cherubim and Seraphim Church in 2004 appointed Akinsowon as the head of the C\&S church in Nigeria with the view of bringing all the divided churches together for peace and harmony.

\section{Reasons for Politics and Divisions amongst Indigenous Pentecostal Groups}

Historical Reason: As indicated above, the schisms and secessions that occurred as a result of politics in the two indigenous Pentecostal churches have strong links with their histories. It could be seen that the British were in charge of government and administration when Christianity spread to Nigeria. Colonization brought new dimensions to Christian missions because it empowered the missionaries to operate freely with the support of the British, Thus, because the British controlled the country, many missionaries were very convinced of the superiority of their culture. There were several cases of victimization or humiliation of native priests in some of the bigger Missions (Olowe: 2007:62-63).

These problems gave way to politics. Some Africans who were not pleased with the attitudes of the missionaries pretended to be loyal so as to retain their posts. However, the end result was divisions. The schism and secessions within Missions began with the Presbyterian Mission in Calabar in 1882, the Lagos Baptist Church in 1888, the United Native African Church in 1891 (Now known as First African Church), the CMS Niger Church in 1892 and The African Church 1901. Such schisms and secessions were barely averted in the Methodist Church, Lagos, 
in 1884 but came eventually in 1917 . (Olowe, 2007: $62)$.

This trend of historical development continued with the arrival of the Faith Tabernacle Movement when the Nigerians disagreed with doctrines and teachings on the ground of divine healing. The end result was secession within the Pentecostal Movement in 1929. Similarly, ten years after, the Nigerians disagreed with the British Apostolic Church for inflating their belief on the use of medicine on them,

Social Reasons: In our discussion, we saw that the Christ Apostolic Church anchors her belief solely on divine healing. Most preachers in the church discouraged youths in higher institutions from studying medicine, banking and law as professional courses in the university. But, many educated youths who studied abroad particularly in late70s, came back home to discourage the teachings on divine healing as against Western medicine. An attempt to carry out these ideas, the educated elites had to go into church politics. They (educated elites) drew to their sides the youths and some leaders in the church who were in support of the youths. The contradiction in ideas and teachings resulted in schism and secession.

Similarly, there was a signal of hanky-panky in the Cherubim and Seraphim church during this said period. It is recalled that the youth in the Cherubim and Seraphim Church admired a leader who could communicate fluently and spiritual gifts of vision and healing ministry for ordinary persons. These qualities mentioned were possessed by Akinsowon and this gave her added advantage over Orimolade during the split because many youths followed her to start the Cherubim and Seraphim Church in Lagos.

Tussle Supremacy: One of the problems in Christ Apostolic Church(CAC) from the 70s upwards is the power tussle for leadership. As earlier mentioned, many gifted ministers in C.A.C. like Timothy Obadare, Bola Are and Bola Odeleke run ministries within the church. They run parallel administrations without obtaining the proper permission from the church authority. We also saw further in the text that the attempts by the ruling church authority to checkmate the powers of these gifted ministers have resulted in conflict and secession. The system of setting up "Ministries" within the "Church" involve church politics, because leaders who engage in such act must be highly connected to the church authority. This accounts for the reasons why leaders close eyes for such decision which contradict the policy of the church. The setting of ministries within the church definitely has negative implications on the centralization and administration of the Christ Apostolic Church.

Similar things happened in the Cherubim and Seraphim Church(C\&S). It began to experience rifts when leaders from different units arrogated power to themselves. The end result was secession. Ayegboyin, an associate Professor from the University of lbadan and priest in the Baptist Church put up in his writing that Akinsowon was power conscious as she was flattered by some youths to break away from Orimolade because of her popularity and gifted power for healing and seeing vision. (Ayegboyin \& Ishola, 2007:85). Also, Ezekiel Davies, the right hand man of Orimolade and also the prayer intercessory director of the church took a similar step and went away with sizeable numbers of the C\&S church to start his ministry. (Akinwumi:, (internet source), 2010: 14).

Leadership attitudes: From the foregoing, it is clear that the non challant attitude of Orimolade contributed to the schism and secession. He organized the C\&S Church from his sitting room. (Akinwumi:, (internet source), 2010: 15). For about four years before he died, he lived in isolation. He hardly came out for church programs and he turned his living room to prayer ground and healing of all sorts. This gap between the leader and the people enabled his chosen ministers to engage in church politics and collude with church members to plot secession. Lekan Akintayo commented "The self acclaimed prophets and ministers deviated from the set goals of the promoter". (Akinwumi: C: (internet source), 2010: 14).

The paper had earlier revealed how some wealthy people in Christ Apostolic Church manipulated the power of the church leaders because of their status in society. They also aspired for higher positions in the church. Some went to the extent of bribing church leaders with gifts of cars, houses etc. thereby preventing them from speaking the truth; and making them loose grip of their positions. Olusheye succinctly concludes on this." The love of money(which the Bible describes as the root of all eveils) the love of material wealth, and the love of position have all led to the current lack of absolute dedication and consecration, among church leaders.(Olusheye,2010:69) Some of these influential and ambitious people who failed in their desire for power finally opted out with many followers. An example was Elder Odegbami of the C.AC. Isale- 
Ake, Abeokuta who opted out to start a Redeemer Church within same locality. (Alokan, O. 2010:20). Odegbami pulled out of the church because the Church leaders did not agree with his ideas particularly that which had to do with church policy.

The Problem of Apostolicship: Another area of sharp differences generating differences in the indigenous churches is the issue of Apostolicship. In the Christ Apostolic Church for instance, only one person has been recognized as an Apostle, and that is in person of Joseph Ayo Babalola-the first General Evangelist of the Church.After his death, many have aspired to resume that time. Infact, today in the Christ Apostolic Church, this issue of Apostolic as a church title have become politicized as many gifted ministers develop interest in that title.

Nevertheless, the Christ Apostolic Church authority has not accorded recognition for this post except Joseph Ayo Babalola. Other church leaders who secretly bear this title have been asked to withdraw it or step out of the church. This decision have led to crisis over the years.

\section{PERSPECTIVES FOR UNITY AND ECUMENICAL UNDERSTANDING}

Christ's will for unity according to the Bible: We begin this reflection by looking at the biblical passage which says: That they all may be one, as thou, father, art in me, and I in thee, that they also may be one in us: that the world may believe that thou hast sent me. (John 17:21). The issues of diversity, schisms and divisions can be likened to what Jesus Christ said in Luke 12:51 that he did not come to bring peace on earth, but division. Though the two biblical references seem contradictory, but could be interpreted that the believers of Jesus would encounter difficulties and challenges on earth; yet they must press forward for unity and love. Thus, the scripture in John 17:23 admonish those who do accept the Christian faith to live in unity.

From this background, unity in the indigenous Pentecostalism can not materialize unless the root causes of disunity are identified; and which have been discussed in this thesis. Also, it is important that Nigerian Pentecostal leaders now see themselves as vineyard and flocks producing fruit in the body of Christ. The body of Christ is one and so the fruit is one. The indigenous Pentecostalism which faces the challenges of rifts and divisions must come together in the ecumenical spirit of oneness through dialogues or respect for one another so as to achieve the desired results of evangelism and winning souls( Mark 16:15).

The Church is the community of people called by God who, through the Holy Spirit, are united with Jesus Christ and sent as disciples to bear witness to God's reconciliation, healing and transformation of creation. Leaders of the indigenous

Pentecostal churches in Nigeria are called to respond to the living word of God by obeying God rather than any human truth( Act 5:29); by repenting of sinful actions, by forgiving others, and by living sacrificial lives of service imbedded in love, joy, peace, patience, kindness, goodness, faithfulness, gentleness and self-control. (Galatians 5:22-23). This aspect is applicable to Christ Apostolic Church leaders to come together, settle their differences and work toward love and unity so as to bring integrity to Christian faith in the world.

The future of indigenous Pentecostalism in Nigeria: Today, though most indigenous Pentecostalism particularly the CAC and C\&S, are passing through tough times of stability, it is discovered that their membership increases daily. The rates in which people troop in to the church become a matter of concern. The main reason for the marvelous attendance is because the liturgy of the church adopts the culture of the local people in terms of songs, dance, dressing and prayer. This is known as enculturation.

According to an author, Olusumbola, CAC local assemblies are more than 10,000 within the country with about ten million worshippers. (Olusumbola, 2001:35). Stephen Glazier also remarked about the C\&S that by the 1950s, the church has spread to other West African countries and in the 1970s to the western world. By the late 1960s, it had about 15,000 congregations in Nigeria. (Glazier, 2001:82).

However, this trend of development may not have positive impact on the future of the churches because of the internal crises. Until the churches settle their scores, the possibility of survival among contemporary churches in the next two decades is slim. The C\&S Church must put more efforts in its recent peace moves to bring some of the scattered assemblies together, particularly with the installation of Akinsowon as the General overseer of C\&S Church, worldwide. In the same way,

Apostle Bada the founder of the Celestial Church of Christ made all efforts to expand the ministry to various parts of Nigeria and also outside the country. 
The ministry was well known in Cameroon and Kotonou in the 80s and especially in early 90 s after the death of Bada, the ministry encountered series of persecutions and divisions; today history has confirmed that the number of worshippers particularly in the Yoruba Western parts of Nigeria are more than five millions.

\section{FINDINGS/RECOMMENDATIONS:}

From the research, it is discovered that the two indigenous Pentecostal churches under study share similar religious worldviews in terms of liturgy, worship and prayers against witches, demons and "familiar" spirits. The differences could be seen in their mode of dressings (CAC dresses in suit and collar shirt while C\&S Church wear white garments) and in the belief towards healing(CAC believes strongly in divine healing while C\&S Church encourages the use of medicine after prayers)

The above findings help to find lasting solutions to the politics and crises in the two churches which have similar backgrounds. From this backdrop, it can be concluded that the problems of indigenous Pentecostalism rest solely on the prophets who are church pioneers and who claimed spiritual superiority without acquiring the training designed for the prophets. The prophetic office has its requirement and is meant for people that could deny themselves of worldly things like Samuel, Moses, Jeremiah, Isaiah, John the Baptist etc did in the Bible. The indigenous Pentecostalism must go back to the Old and New Testament scriptures to see the love, joy, readiness and prestige attached to prophetic office.

In conclusion, this paper has given reasons for schism, politics and secession among indigenous Pentecostals in Nigeria with reference to Christ Apostolic Church and Cherubim and Seraphim Church. Therefore the heart of maintaining unity and love in the divided churches is through dialogue. It is the only means of fostering relationships that will lead toward reconciliation. There is no doubt the CAC and C\&S have contributed their quota to the growth of indigenous Pentecostalism in Nigeria. However, the fact remains that the development in the CAC and C\&S today has not shown that they have set the pace for Pentecostal churches in Nigeria.

Today, schisms and secessions have become parts of the history of the church and it is bringing dirt to Christendom. The crises are getting out of hand and many unbelievers watch with keen interest the ugly situations. Also, the churches will continue to loose their credibility as their sons and daughters make options for new denominations that are recently springing up. Such new denominations include; The Deeper Life Bible Church, The Gospel Faith Mission, The Redeemed Christian Church of God, The Apostolic Faith among others.

\section{REFERENCES}

Adegboyega, S.G. (1978) Short History of the Apostolic Church in Nigeria, Ibadan: Rosprint Industrial Press Ltd.

Ademola, I. \& Ayegboyin, D. (2005) Rediscovering and fostering unity in the body of Christ: The Nigerian Experience, Lagos: ATF Publications.

Ajayi, J.F.A.(1965) Christian Missions in Nigeria, 18411891, London: Longman Press Publications.

Anderson, Allan (2004) An Introduction to Pentecostalism, Oxford: Cambridge University Press.

Alokan Adeware (1991) The Christ Apostolic Church (19281988), Lagos: Ibukunola printing press.

Alokan, Adeware, (2000) Cradle and Beyond), lle-lfe: Timade Ventures Ayegboyin, D. \& Ishola, S.A. (1997)

Alokan Adeware(2010)Christ Apostolic Church at 90, lle-Ife,Timade Ventures.

African Indigenous Churches: An Historical Perspective Lagos: Greater Heights Publications. Best Thomas \& Heller Dagmar (eds) (2004) Worship Today: Understanding, Practice, Ecumenical Implications, Geneva: WCC Publications.Best Thomas \& Heller Dagmar (1995) So We Believe, So We Pray, Geneva: WCC Publications.

Edwards David (1998) Christianity, the First Two Thousand Years, London: Redwood Publishing Book.Grimley, J.B: \& Ropbinson G.E (1966) Church Growth in Central and Southern Nigerian, London: Grand Rapids.

Groves Charles (2002) The Planting of Christianity in Africa: Library of Ecclesiastical History, Cambridge: James Clarke \& Co.

Hastings, A (1967) African Christianity, London: Q.U.P.

Kalu Ogbu (2008) African Pentecostalism: An Introduction, New York: Oxford University Press.

Lucas Phillip (2004) New Religious Movements in the $21^{\text {st }}$ Century, New York: Routledge Publications.

Marshall Ruth (2009) Political Spiritualities. The Pentecostal Revolution in Nigeria, Chicago: University of Chicago Press.

Mcrath, Alister, Heresy (2009) A History of Defending the truth; London: Ashford Colour Press. 
Ndiokwere Nathaniel (1981) Prophecy and Revolution: The Role of prophets in the Independent African Churches and in Biblical Traditions, London: Camelot Press Ltd.

Nyamiti Charles (2007) Studies in African Theology: Some Contemporary Models of African Ecclesiology: A Critical Assessment in the light of Biblical \& Church Teaching, Nairobi: CUEA Publications.

Olayiwola David (2009) The Anglican Church in Egbaland, History of its Genesis, Development and Impact, Abeokuta: Gbemi Sodipo Press Ltd.

Omoyajowo, Akinyele (1982) Cherubim and Seraphim: The History of an African Independent Church, Lagos: NOK Publications.

Omoyajowo Akinyele (1982) Diversity in Unity: The Development and Expansion of the C\&S Church in Nigeria, Lanhan: UP of America Press.

Omoyajowo Akinyele (2001) Religion, Society and the Home, ljebu Ode: Vicoo International Press.

Olusheye Elijah(2010) The legacies of our Patriarchs

Ibadan ,Gideon Global Press.

Oshitelu Rufus (2007) History of the Aladura (Independent) Churches, 1918-1940 an Interpretation, Ibadan: Hope Publications Ltd.
Oshitelu Rufus (2002) African Instituted Churches: Diversities, Growth, Gifts, Spirituality and Ecumenical Understanding London: Hamburg,

Olowe, Abi (2007) Great Revivals, Great Revivalist, Joseph Ayo Babalola, Texas: Omega Publishers Houston.

Onovughakpo, S. (1971) History and Doctrine of the C\&S (Nigeria), Warri: Midland Press.

Peel, J.D.Y. (1968) Aladura: A Religious Movement among the Youth, London: Oxford press.

Porterfield Amanda (2005) Healing in the History of Christianity, New York: Oxford University Press.

Rouse, Ruth and Neill (2004) Charles (eds), A History of the Ecumenical Movement 1517-1948 Volume 1,Geneva: WCC publications.

Thorogood Bernard (2010) Gales of Changes; Responding to a Shifting Missionary Context, Geneva: WCC Publications, 2010.

Turner Harold (1979) Religious Innovation in Africa: collected Essays on New Religious Movements, London: G.K.Hall \& Company.

Website, J.V (1964) The African Church among the Yoruba; Oxford: Clarendon Press.

Welsh Robert, Ecumenical Exercise IV, The Wesleyan Church, The Christ Apostolic Church and Mennonites, Faith and Order paper, no 79. 